\title{
Health Risk Assessment of Swimming Pool Users from the Effects of Legionella Spp. Contamination of Water
}

\author{
Izabela Zimoch ${ }^{1 *}$, Jarosław Paciej ${ }^{1}$ \\ 1 Silesian University of Technology, Faculty of Energy and Environmental Engineering, Institute of Water and \\ Wastewater Engineering, ul. Konarskiego 18, 44-100 Gliwice, Poland \\ 2 Silesian Waterworks PLC, ul. Wojewódzka 19, 40-026 Katowice, Poland \\ * Corresponding author's e-mail: izabela.zimoch@polsl.pl
}

\begin{abstract}
One of the main problems in the scope of public health is poor identification of the waterborne diseases and their etiology. One of the aims of the new directive concerning the quality of water intended for human consumption is to implement the principles of hazard assessment in water supply systems (WSS) in the member states, on the basis of water quality monitoring and analyses of the system functioning conditions. The implementation of risk management procedures in WSSs is to ensure an increase in the water supply safety and, in turn, protect the consumer's health against the harmful effects of any potable water contamination. At present, the secondary legislation to the Polish acts implementing the Directive of the Council of Europe is the Regulation of the Minister of Health on the quality of water intended for human consumption, which also sets forth the scope of monitoring the quality of hot water for Legionella spp., which can be an etiological factor of legionellosis. Another act regulating the water quality in terms of Legionella spp. is the Regulation of the Minister of Health on water quality in swimming pools. These acts, referring to the parameter of Legionella spp., are complementary. This paper presents the results of evaluating the change in the sanitary status of hot water quality in terms of contamination with Legionella spp. bacteria in the selected swimming pool facilities in southern Poland (Silesian Voivodship). On the basis of the available water quality test from state inspections (Chief Sanitary Inspectorate), an analysis of the microbiological quality of hot water in swimming pools was conducted. The analyses included a spatial distribution of those facilities, which results from the regionalisation subject to the territorially competent public health authority exercising supervision over the water quality in the Silesian Voivodship. The methods were presented for determination of the health risk of swimming pool users as a result of contamination of swimming pool water with Legionella spp. in relation to the availability of a given recreation facility. The final result of these studies is the use of GIS (Geographic Information System) tools in spatial risk interpretation.
\end{abstract}

Keywords: Legionella spp., swimming pools, health risk assessment, GIS technologies, water quality control

\section{INTRODUCTION}

Water is the basic element ensuring the development of life on Earth. The preamble to the Water Framework Directive (WFD) specified that water is not a commercial product like any other but, rather, a heritage which must be protected, defended and treated as such [Directive, 2000]. What supplements WFD is Drinking Water Directive (DWD) [Directive, 1998], the primary objective of which is to protect the human health against the detrimental effects of any contamination of tap water. An act complementing the human health protection against waterborne diseases is Bathing Water Directive [Directive, 2006] concerning the management of bathing water quality. In Poland, the legal act regulating the issues of safety of people remaining in swimming pools is a Health Minister Regulation [Polish Journal of Laws, 2015]. The Regulation specifies the requirements imposed on the quality of the water in recreation and sports facilities and the water in showers as well as the terms of monitoring of that quality. According to those provisions, the water in swimming pools is inspected for potential microbiological 
contamination in terms of: Escherichia coli, Pseudomonas aeruginosa, the total number of microorganisms at $36 \pm 2{ }^{\circ} \mathrm{C}$ after $48 \mathrm{~h}$, coagulase positive staphylococci and Legionella spp. Those microorganisms are regarded as the markers of waterborne diseases. For instance, Legionella pneumophila is a pathogen of legionellosis, or pneumonia with a high mortality rate. The cause of legionellosis was found in 1976 after an epidemic, which broke out among the American veterans participating in the American Legion Convention in Philadelphia [Terranova, Cohen and Fraser, 1978]. The event proved that the etiology of legionellosis is the water contaminated with the Legionella-type bacteria.

Legionella are Gram-negative bacteria occurring both in the natural water environment and in water supply systems, where they can grow at $25-43^{\circ} \mathrm{C}$ and can survive at temperatures of $55-60^{\circ} \mathrm{C}$ without the possibility of reproducing themselves. Water supply systems create the favourable development conditions for those bacteria both by providing higher temperature at plumbing systems, which eliminates the growth of other bacteria, and by stagnation of water in the installation, which leads to the formation of a biofilm rich in organic matter [Leoni et al., 2001, Napoli et al., 2010, Principe, Tomao and Visca, 2017]. Therefore, intense development of Legionella is a real threat in every facility with a hot water installation [Lee, 2013, McCoy et al., 2012, Goutziana et al., 2008]. One of methods for the efficient protection of hot water-using devices exposed to the growth of Legionella spp. is the thermal disinfection of plumbing installations, consisting in the creation of the environmental conditions at intake points that cause the cell death (maintenance of water temperature in the scope from $70^{\circ} \mathrm{C}$ to $80^{\circ} \mathrm{C}$ ).

Legionella spp. may cause the so-called Legionnaires' disease and Pontiac fever in humans. The prime route of the human exposure to these microorganisms is the inhalation tract. In many countries of Europe there are institutions dealing with the identification of waterborne diseases, e.g. the National Public Health Institute in Finland, the Health Protection Agency in Great Britain, the Robert Koch Institute in Germany, the National Institute for Public Health and the Environment in the Netherlands, the National Institute for Public Health Surveillance in France or the Swedish Institute for Infectious Disease Control in Sweden. Unfortunately, there is still no obligation in Poland to keep a register of such diseases. In the world, the USA holds the leading position in implementation of health protection systems. Here, on the initiative of CDC (Centres for Disease Control and Prevention) in cooperation with the U.S. Environmental Protection Agency (EPA) and the Council of State and Territorial Epidemiologists, the Waterborne Disease and Outbreak Surveillance System (WBDOSS) has been implemented since 1971. WBDOSS is a system gathering the data on the events and causes of occurrence of foci of disease and their health effects. According to CDC's report of 2013 [CDC, 2013], as many as 1758 diseases were induced by tap water in the USA in years 1971-2010. The reported waterborne diseases affected more than 600,000 people, 365 out of which died. From 1,748 foci of disease, $48 \%$ ( 851 cases) were related to potable water and $44 \%$ ( 777 cases) with the water used in the recreation industry [CDC, 2013]. In years 2011-2012, in 17 states 32 cases of diseases induced by potable water were confirmed, which led to 431 people developing diseases as a result of which 102 people were hospitalised and 14 people died. The most frequently identified factor of disease included the Legionella bacteria, which caused as much as $66 \%$ of disease events, including 8 deaths [Beer et al., 2015].

The pathogens being the cause of waterborne diseases, ones that colonise water supply systems, may result from raw water, improperly treated water, contaminated network water bodies or distribution systems that are not tight, but also from internal water supply installations [Beauté, Zucs and de Jong, 2013, Roig, Sabria and Petro-Botet, 2003]. Despite the application of the water treatment processes, including its disinfection with chlorine compounds, tap water may be contaminated microbiologically and pose a serious threat to the health of its users and consumers. According to the reports of CDC, the contamination of water with Legionella causes the highest mortality rate (58\%) among the identified waterborne diseases [CDC, 2013]. Therefore, it is extremely important to analyse threats related to the microbiological contamination of water, including the installations and devices where hot water is used and where water-air aerosol producing devices are applied. Such facilities generating high threat of Legionella infection for humans include sports and recreation swimming pool complexes. 


\section{CHARACTERISTICS OF RESEARCH SUBJECT}

The study was conducted in public swimming pool facilities located in southern Poland, in the Silesian Voivodship. The Voivodship is an administrative division unit with the area of $12,333.09 \mathrm{~km}^{2}$. It covers the eastern part of Upper Silesia and the western part of Lesser Poland, including the Dąbrowa Basin, the Kraków Basin, the Żywiec Region and the city of Częstochowa. The Voivodship is inhabited by 4.57 million people. This is the Voivodship with the highest level of urbanisation and population density in Poland (370.1 people per square $\mathrm{km}$ ) and the largest cluster of cities of more than 100 thousand of inhabitants. This is the only one voivodship in Poland to have fewer districts (17) than cities with districts rights (19).

In the Silesian Voivodship 302 swimming pool complexes were registered in 2016, in 2017 -285 and in $2018-287$ (Table 1). The administrative division does not determine the number of public swimming pools in individual areas of the Silesian region. As a result, the distribution of those facilities is not uniform across the voivodship and fluctuates every year. For instance, in one of the largest districts in Poland, i.e. the district of Czestochowa, inhabited by ca. 135 thousand people, there are no swimming pools, while in Bielsko-Biała (a city with district rights) there were 15 swimming pool complexes in 2016 year and only 11 in 2018 year. Furthermore, in the area of the Bielsko-Biała district, the number of swimming pools was reduced by as much as $30 \%$ from 10 swimming pools in 2016 year to 7 in 2018 year. The conducted analysis of the public swimming pool complexes registered in the Silesian Voivodship in 2016-2018 showed that nearly $30 \%$ of the facilities were the swimming pools in schools and $15 \%$ were the swimming pools located in hotels. Over the entire time horizon of the testing, 10 aqua park facilities were operating there. Those facilities featured both indoor and outdoor pools. Ca. $27 \%$ of the total number of facilities are seasonal swimming pools open in summertime only and in $30 \%$ of them the water-air aerosol generating devices were applied [SSI, 2019].

The studies were conducted on the basis of the data from years 2016-2018, collected in the databases of the Silesian Voivodship Inspector of the State Sanitary Inspection, archiving the parameters of quality of water in the swimming pools in the Silesian Voivodship [SSI, 2019]. Moreover, the statistical data of Statistics Poland were used [Statistics Poland, 2019].

\section{RESEARCH METHOD}

In Poland, there are two legal acts regarding the quality of water intended for human consumption [Polish Journal of Laws, 2017] and the quality of swimming pools water [Polish Journal of Laws, 2015], in which the microbiological parameters of water quality to be met by drinking or sanitary hot water were specified precisely. In the first of those regulations [Polish Journal of Laws, 2017], the obligation to test hot water for the presence of Legionella spp. was imposed on the facilities with round-the-clock healthcare services (i.e. hospitals, sanatoriums and healthcare homes) as well as the collective residence buildings and public utility buildings where the air-water aerosol is generated during their use. On the other hand, the regulation concerning the quality of water in swimming pools [Polish Journal of Laws, 2015] imposed the obligation for the microbiological water testing on the swimming pool administrator. According to that regulation, the presence of Legionella spp. is to be monitored:

- in the water introduced in the swimming pool basin from the circulation system,

- in the water in the swimming pool basins, including paddling pools, when the water temperature is higher than $30^{\circ} \mathrm{C}$,

- in the water in the basins equipped with the water-air aerosol generating devices,

- in the water in swimming pool basins made available for teaching babies and small children up to the age of 3 how to swim,

- in showers.

According to the regulation, for the reasons related to the health of swimming pool users, $\mathrm{Le}$ gionella spp. is not allowed to be present in the circulation water and the swimming pool basin water. At the same time, the regulation defines the frequency at which the hot water sampled from showers is to be tested, depending on the level of its contamination (Table 2).

On the basis of the legal requirements effective in Poland [Polish Journal of Laws, 2015], in the tests for the presence of Legionella spp. in swimming pool facilities have to be carried out 4 times a year: in the water introduced in the 
Table 1. Specification of the number of swimming pool complexes in individual districts of the Silesian Voivodship in 2016-2018 [SSI, 2019]

\begin{tabular}{|c|c|c|c|c|c|}
\hline \multirow{2}{*}{ District } & \multirow{2}{*}{ District No } & \multicolumn{3}{|c|}{ Number of swimming pool complex } & \multirow{2}{*}{$\begin{array}{c}\text { Population size } \\
\text { [thous. of inhabitants] }\end{array}$} \\
\hline & & 2016 & 2017 & 2018 & \\
\hline D. będziński & 2401 & 3 & 3 & 3 & 149.9 \\
\hline D. bielski & 2402 & 16 & 17 & 16 & 162.5 \\
\hline D. cieszyński & 2403 & 27 & 27 & 29 & 177.4 \\
\hline D. częstochowski & 2404 & \multicolumn{3}{|c|}{ Brak basenów } & 135.5 \\
\hline D. gliwicki & 2405 & 7 & 7 & 7 & 115.3 \\
\hline D. kłobucki & 2406 & 3 & 3 & 3 & 85.1 \\
\hline D. lubliniecki & 2407 & 6 & 5 & 5 & 76.9 \\
\hline D. mikołowski & 2408 & 3 & 3 & 3 & 96.7 \\
\hline D. myszkowski & 2409 & 4 & 1 & 2 & 71.7 \\
\hline D. pszczyński & 2410 & 12 & 11 & 11 & 109.9 \\
\hline D. raciborski & 2411 & 7 & 7 & 7 & 109.0 \\
\hline D. rybnicki & 2412 & 2 & 2 & 2 & 77.5 \\
\hline D. tarnogórski & 2413 & 6 & 6 & 6 & 139.0 \\
\hline D. bieruńsko-lędziński & 2414 & 4 & 4 & 4 & 59.0 \\
\hline D. wodzisławski & 2415 & 7 & 7 & 7 & 157.8 \\
\hline D. zawierciański & 2416 & 17 & 16 & 16 & 120.0 \\
\hline D. żywiecki & 2417 & 27 & 26 & 26 & 153.0 \\
\hline CDR. Bielsko-Biała & 2461 & 13 & 13 & 13 & 172.4 \\
\hline CDR. Bytom & 2462 & 6 & 6 & 6 & 170.1 \\
\hline CDR. Chorzów & 2463 & 9 & 7 & 7 & 109.5 \\
\hline CDR. Częstochowa & 2464 & 9 & 9 & 8 & 227.3 \\
\hline CDR. Dąbrowa Górnicza & 2465 & 12 & 11 & 11 & 122.4 \\
\hline CDR. Gliwice & 2466 & 10 & 10 & 10 & 183.0 \\
\hline CDR. Jastrzębie-Zdrój & 2467 & 3 & 3 & 3 & 90.2 \\
\hline CDR. Jaworzno & 2468 & 2 & 2 & 2 & 92.6 \\
\hline CDR. Katowice & 2469 & 38 & 35 & 34 & 299.0 \\
\hline CDR. Mysłowice & 2470 & 3 & 3 & 2 & 74.7 \\
\hline CDR. Piekary Śląskie & 2471 & 4 & 2 & 2 & 56.1 \\
\hline CDR. Ruda Śląska & 2472 & 5 & 5 & 5 & 139.4 \\
\hline CDR. Rybnik & 2473 & 6 & 6 & 6 & 139.5 \\
\hline CDR. Siemianowice Śląskie & 2474 & 5 & 3 & 4 & 68.0 \\
\hline CDR. Sosnowiec & 2475 & 9 & 9 & 10 & 206.5 \\
\hline CDR. Świętochłowice & 2476 & 3 & 3 & 3 & 50.7 \\
\hline CDR. Tychy & 2477 & 6 & 6 & 7 & 128.4 \\
\hline CDR. Zabrze & 2478 & 6 & 6 & 6 & 175.9 \\
\hline CDR. Żory & 2479 & 2 & 1 & 1 & 61.9 \\
\hline
\end{tabular}

$\mathrm{D}$ - district; CDR - city with district rights.

Table 2. Classification of water contamination level in showers along with the frequency of sampling for testing [Polish Journal of Laws, 2015]

\begin{tabular}{|c|c|l|}
\hline $\begin{array}{c}\text { Number of Legionella } \\
\text { spp. [CFU/100 mL] }\end{array}$ & $\begin{array}{c}\text { Contamination } \\
\text { category }\end{array}$ & Procedure for dealing \\
\hline$\leq 100$ & insignificant & $\begin{array}{l}\text { After 3 years, or after 1 year if no or scarce contamination was found on two } \\
\text { consecutive tests performed at yearly intervals. }\end{array}$ \\
\hline $101-1000$ & medium & $\begin{array}{l}\text { After } 4 \text { weeks, if the result does not change, the cleaning and disinfection is } \\
\text { to be carried out, the test is to be repeated after } 1 \text { week and then after } 1 \text { year. }\end{array}$ \\
\hline $1001-10000$ & high & $\begin{array}{l}\text { After 1 week from cleaning and disinfection and then every } 3 \text { months. If on } \\
\text { two consecutive tests performed at the interval of three months less than } \\
100 \text { CFU/100 mL are found, the next test can be performed in a year. }\end{array}$ \\
\hline$>10000$ & very high & $\begin{array}{l}\text { After 1 week from cleaning and disinfection and then every } 3 \text { months. If on } \\
\text { two consecutive tests performed at the interval of three months less than } \\
100 \text { CFUs/100 mL are found, the next test can be performed in a year. }\end{array}$ \\
\hline
\end{tabular}


swimming pool basin from the circulation system, in the water in the basins where the water temperature is higher than $30^{\circ} \mathrm{C}$ as well as in the water in the swimming pool made available for teaching babies and small children up to the age of 3 how to swim. On the other hand, in the case of the swimming pool basins equipped with the water-air aerosol generating devices, water must be tested for the presence of Legionella spp. 12 times a year. According to the Polish law, if $L e$ gionella spp. is found in the circulation water and in the swimming pool basins, the supervisory authority, i.e. a competent State Sanitary Inspector, should to take an administrative decision on excluding the facility from use and imposing a financial penalty on the swimming pool administrator. If a waterborne disease is confirmed in swimming pool complex users, the facility owner may be sued in court for jeopardising the health and life of people using those that facility. The microbiological contamination always generates the health risk for swimming pool users and higher costs, borne by the swimming pool owner for introducing the repair activities, as well as lowers the trust of swimming pool users in the quality of the provided services. The above-mentioned state justifies the necessity to develop the methods for assessing the health risk of swimming pool users as a result of the Legionella spp. contamination of water with its spatial interpretation.

As the water in showers and the water in circulation, supplying the swimming pool, is fed from the same water treatment system and taking into account that full public health protection is provided to the people using swimming pools, two water quality states were defined in the research model:

- state one (S1) is the state of loss of microbiological safety of water, defined by the presence of at least one colony-forming unit of Legionella spp. in $100 \mathrm{~mL}$;

- state two (S2) is the state of microbiological safety of water, defined by the complete absence of Legionella spp. in water.
In the research methods, on the basis of Polish regulation [Polish Journal of Laws, 2015], each $i^{\text {th }}$ category of Legionella spp. contamination category was given a weight $W_{j, i}(C C)$ (Table 3 ) identifying the water contamination level in the $j^{\text {th }}$ swimming pool complex. On the basis of the collected data, for each $j^{\text {th }}$ swimming pool complex, the index of hazard sensitivity $I H S_{j}$ is determined in the analysed time horizon according to the following formula:

$$
I H S_{j}=\sum_{i=1}^{4} P_{j, i} \cdot W_{j, i}(C C)
$$

where: $W_{j, i}(C C)$ - the value of the weight for the $i^{\text {th }}$ category of contamination (insignificant, moderate, high, very high) occurring in the $j^{\text {th }}$ swimming pool complex (Table 3 ),

$P_{j, i}-$ the probability of occurrence of the $i^{t, i}$ category of contamination in the $j^{\text {th }}$ swimming pool complex in a given time horizon.

The probability $P_{j, i}$ of occurrence of the $i^{\text {th }}$ category of contamination in the $j^{\text {th }}$ swimming pool complex over a given study horizon is determined according to the following formula:

$$
P_{j, i}=\frac{N_{j, i}(C C)}{N_{j}}
$$

where: $N_{j, i}(C C)$ - the number of water samples where the $i^{\text {th }}$ category of contamination was found in the $j^{\text {th }}$ swimming pool complex in a given study horizon,

$N_{j}$ - the number of all water samples where Legionella spp. was tested in the $j^{\text {th }}$ swimming pool complex in a given study horizon.

The determination of the contamination sensitivity index for each $j^{\text {th }}$ swimming pool complex allows, at the next stage of the research methods, determining the value of index of area hazard sensitivity $I S H S_{k}$ in any separated $k^{\text {th }}$ analysis area according to the following formula:

Table 3. Categorization of the Legionella spp. contamination level

\begin{tabular}{|c|c|c|c|}
\hline $\begin{array}{c}\text { Number of contamination } \\
\text { category } i\end{array}$ & $\begin{array}{c}\text { Number of Legionella spp. } \\
{[\text { CFU/100 mL] }}\end{array}$ & Contamination category CC & Contamination weight $W_{j, i}(C C)$ \\
\hline 1 & & insignificant & 1 \\
\hline 2 & & medium & 2 \\
\hline 3 & migh & 3 \\
\hline 4 & more than 10000 & very high & 4 \\
\hline
\end{tabular}




$$
I A H S_{k}=\sum_{j=1}^{J} I H S_{j}
$$

where: $k$ - the $k^{\text {th }}$ analysis area, determined on the basis of the criterion of the division of the study area into smaller areas, e.g. division according to the administrative borders of districts, or according to the separated areas of state monitoring of swimming pool water quality etc.,

$J$ - the number of all swimming pool complexes in a given $k^{\text {th }}$ analysis area,

$I H S_{j}$ - index of hazard sensitivity of risk of water contamination with Legionella spp. in the $j^{\text {th }}$ swimming pool complex, in the $k$ th study area.

In order to determine the spatial risk of exposure to waterborne diseases having their etiology in the presence of Legionella spp. in the water used in swimming pool complexes, it is necessary to categorise swimming pools due to their size in order to define the significance weights of these facility. The categorisation is performed on the basis of the number of basins in a swimming complex (Table 4).

An integral part of risk assessment is the determination of a verified number of swimming pools $J V_{k}$ defining the averaged number of swimming pool basins in all swimming pool complexes in the $k^{\text {th }}$ study area:

$$
J V_{k}=C_{a} \cdot J
$$

where: $J$ - number of all swimming pool complexes in a given kth study area, $C_{a}$ - coefficient of the availability of swimming pool basins determined according to formula 5 :

$$
C_{a}=\sum_{n=1}^{3} a_{n} \cdot W_{n}(S P C)
$$

where: $W_{n}(S P C)$ - value of the weight for the $n^{\text {th }}$ category of the swimming pool complex, $a_{n}=J_{n} \mid J$ - percentage share of the swimming pool complexes of the $n^{\text {th }}$ category in the total number of swimming pool complexes in the $k^{\text {th }}$ study area:

$J_{n}$ - number of swimming pool complexes of the $n^{\text {th }}$ category.
The next stage of the research method is the determination of the swimming pool complex load index $L I(S P C)_{k}$ in the $k^{\text {th }}$ study area, which is interpreted as a parameter of effects of potential disease of public swimming pool users exposed to microbiological contaminations:

$$
L I(S P C)_{k}=\frac{P N_{k}}{J V_{k}}
$$

where: $P N_{k}$ - population size in the $k^{\text {th }}$ study area, $J V_{k}-$ verified number of swimming pools in the $k^{\text {th }}$ study area.

In the assessment of the health risk for swimming pool users as a result of contamination of water with Legionella spp., the matrix method for risk estimation is used, where the risk in the $k^{\text {th }}$ study area is defined with the following formula:

$$
R_{k}=W_{I A H S_{k}} \cdot W_{L I(S P C)_{k}}
$$

where: $R_{k}$ - health risk of swimming pool users in the $k^{\text {th }}$ study area as a result of contamination of swimming pool water with Legionella spp.,

$W_{\text {IAHS }}$ - value of the weight of area hazard sensitivity index in the $k^{\text {th }}$ study area (Table 5),

$W_{L I(S P)_{k}}$ - value of the weight of the swimming pool complex load index in the $k^{\text {th }}$ study area (Table 5).

In the research method, in order to determine the three-degree scale of risk variables, their weights are determined on the basis of the threshold values of the area hazard sensitivity index and the facility load index. To that end, $\mathrm{H}_{0}$ hypothesis about the compliance of the empirical distribution of risk variables with the normal distribution was verified. In order to assess the compliance of the distribution of a set of random variables $I A H S_{k}$ and $L I(S P C)_{k}$ with the normal distribution, the Kolmogorov-Smirnov test $(\mathrm{K}-\mathrm{S})$ and $\chi^{2}$ test for significance levels $\alpha=0.01$ for the K-S test and $\alpha=0.05$ for the $\chi^{2}$ test were used. If the compliance of the analysed distribution with the normal distribution is confirmed, the thresholds of random variable values are defined by the value of the mean $(\mu)$

Table 4. Categorisation of swimming pool complex according to the number of basins

\begin{tabular}{|c|c|c|c|}
\hline $\begin{array}{c}\text { Size category of } \\
\text { swimming pool complex SPC }\end{array}$ & $\begin{array}{c}\text { Category number } \\
n\end{array}$ & $\begin{array}{c}\text { Number of swimming pool } \\
\text { basins criterion }\end{array}$ & $\begin{array}{c}\text { Weight of swimming pool } \\
\text { complex }_{n}(S P C)\end{array}$ \\
\hline$S P C$ - small & 1 & 1 & 1 \\
\hline$S P C$ - medium & 2 & 2 or 3 & 3 \\
\hline$S P C$ - high & 3 & more than 3 & 5 \\
\hline
\end{tabular}


Table 5. Two-parameter matrix of health risk for swimming pool users as a result of contamination of swimming pool water with Legionella spp.

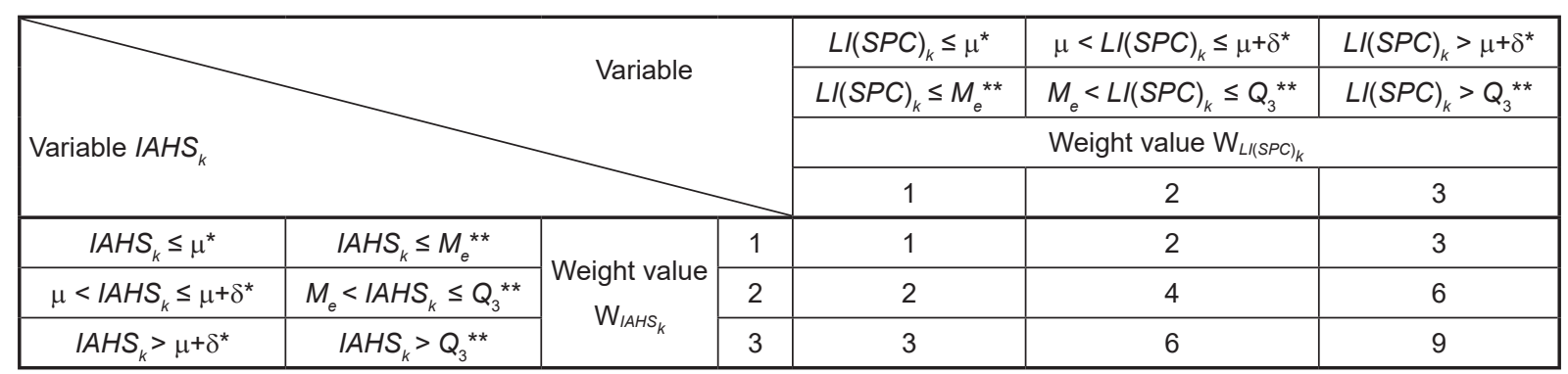

* the thresholds of random variable values if zero hypothesis $\mathrm{H}_{0}$ is true,

** the thresholds of random variable values if zero hypothesis $\mathrm{H}_{0}$ is rejected.

and sum of the mean and the standard deviation $(\mu+\delta)$ and if zero hypothesis $\left(\mathrm{H}_{0}\right)$ is rejected, the value thresholds are determined with the medina $(M e)$ and the third quartile $\left(Q_{3}\right)$. The set threshold values of the variation intervals allow to allocate the weights to variables in three intervals (Table 5). The mathematical interpretation of the risk, as a function of probability of hazard events and their effects expressed with weights of those variables, allows determining the values of risks by formula 7 in the matrix method. Those values are the basis for allocating the $k^{\text {th }}$ study area to a given risk category on its three-degree scale: tolerated, controlled and unacceptable (Table 6).

At the last stage of the research method, the spatial interpretation of the risk for the obtained study results is performed with GIS software used in spatial analyses.

Table 6. Classification of health risk for swimming pool users as a result of water contamination with Legionella spp.

\begin{tabular}{|l|c|}
\hline \multicolumn{1}{|c|}{ Risk category } & Risk value $R_{k}$ \\
\hline Tolerated risk & $1-2$ \\
\hline Controlled risk & $3-4$ \\
\hline Unacceptable risk & $6-9$ \\
\hline
\end{tabular}

\section{RESULTS AND DISCUSSION}

The analysis covered the results of the water quality tests conducted in 2016-2018 for the presence of Legionella spp. in the samples collected in the swimming pools in the Silesian Voivodships. These data were obtained from the databases of the Voivodship Sanitary-Epidemiology Station in Katowice [SSI, 2019]. The collected data were aggregated to areas of districts (city - CRD and country districts $-\mathrm{D}$ ), being 35 separated study areas. Only in the Częstochowa district there was no swimming pool complex in the analysed time horizon. Therefore, this area was excluded from the analysis. The obtained data were ordered and verified. Next, the obtained data set of parameters of microbiological quality of water in the swimming pools were examined in terms of the risk assessment for potential water contamination with Legionella spp. In the verified set of data, the cases where at least one sample exhibited the state of lost microbiological safety of water (S1), defined by the presence of at least one colonyforming unit of Legionella spp. in $100 \mathrm{~mL}$, were separated (Table 7).

According to the proposed research method, for each $j^{\text {th }}$ swimming pool complex index of hazard sensitivity $I H S_{j}$ was determined. The obtained set of random variables was subjected to a statistical analysis (Table 8).

The conducted statistical analysis of index of hazard sensitivity showed that its maximum value in the set study periods occurred for the swimming pool complexes in cities with district rights (2016 - city of Katowice, 2017 - city of Bielsko-Biała, 2018 - city of Częstochowa). The water quality in the swimming pool complexes in all Silesian Voivodship, in the period when the studies were performed (Table 9), was characterised by the $\mathrm{S} 2$ water quality state, which guarantees full microbiological safety of water (no Legionella spp. in water) in nearly $90 \%$ of cases. The probability of the S2 state varied from 0.889 to 0.927 . If the S1 water quality state occurred in the swimming pool complexes of the Silesian Voivodship, the microbiological contamination of water in $5 \%$ of cases on average corresponded to the contamination category 
Table 7. The list of swimming pools in the Silesian Voivodships which were tested for potential water contamination with Legionella spp. in years 2016-2018

\begin{tabular}{|c|c|c|c|c|c|c|c|}
\hline \multirow[t]{2}{*}{ District } & \multirow[t]{2}{*}{ District No } & \multicolumn{3}{|c|}{$\begin{array}{l}\text { Number of swimming pool } \\
\text { complexes J }\end{array}$} & \multicolumn{3}{|c|}{$\begin{array}{l}\text { Number of swimming pool complexes } \\
\text { in which the S1 state occurred }\end{array}$} \\
\hline & & 2016 & 2017 & 2018 & 2016 & 2017 & 2018 \\
\hline D. będziński & 2401 & 1 & 4 & 3 & 1 & 2 & - \\
\hline D. bielski & 2402 & 12 & 15 & 11 & 1 & 13 & - \\
\hline D. cieszyński & 2403 & 18 & 26 & 25 & 3 & 12 & 10 \\
\hline D. gliwicki & 2405 & 6 & 7 & 7 & 3 & 3 & 4 \\
\hline D. kłobucki & 2406 & 2 & 2 & 2 & 0 & 1 & - \\
\hline D. lubliniecki & 2407 & 1 & 4 & 2 & 0 & 1 & - \\
\hline D. mikołowski & 2408 & 3 & 3 & 3 & 0 & 0 & 1 \\
\hline D. myszkowski & 2409 & 1 & 1 & 1 & 1 & 0 & 1 \\
\hline D. pszczyński & 2410 & 8 & 9 & 9 & 0 & 3 & 4 \\
\hline D. raciborski & 2411 & 5 & 7 & 3 & 0 & 1 & 2 \\
\hline D. rybnicki & 2412 & 2 & 2 & 2 & 0 & 0 & - \\
\hline D. tarnogórski & 2413 & 4 & 4 & 4 & 1 & 2 & 2 \\
\hline D. bieruńsko-lędziński & 2414 & 2 & 3 & 3 & 1 & 1 & 1 \\
\hline D. wodzisławski & 2415 & 7 & 7 & 7 & 3 & 3 & 2 \\
\hline D. zawierciański & 2416 & 7 & 9 & 8 & 0 & 6 & 4 \\
\hline D. żywiecki & 2417 & 16 & 22 & 16 & 0 & 9 & 2 \\
\hline CDR. Bielsko-Biała & 2461 & 10 & 11 & 7 & 4 & 10 & 1 \\
\hline CDR. Bytom & 2462 & 6 & 6 & 6 & 2 & 4 & 3 \\
\hline CDR. Chorzów & 2463 & 6 & 7 & 7 & 0 & 2 & 2 \\
\hline CDR. Częstochowa & 2464 & 8 & 8 & 7 & 4 & 6 & 4 \\
\hline CDR. Dąbrowa Górnicza & 2465 & 10 & 12 & 8 & 9 & 11 & 6 \\
\hline CDR. Gliwice & 2466 & 9 & 10 & 10 & 1 & 9 & 9 \\
\hline CDR. Jastrzębie-Zdrój & 2467 & 3 & 3 & 3 & 1 & 2 & 2 \\
\hline CDR. Jaworzno & 2468 & 3 & 2 & 2 & 1 & 2 & 1 \\
\hline CDR. Katowice & 2469 & 34 & 36 & 33 & 10 & 20 & 15 \\
\hline CDR. Mysłowice & 2470 & 4 & 4 & 3 & 2 & 1 & 1 \\
\hline CDR. Piekary Śląskie & 2471 & 3 & 2 & 2 & 1 & 2 & 1 \\
\hline CDR. Ruda Śląska & 2472 & 5 & 5 & 5 & 4 & 2 & 2 \\
\hline CDR. Rybnik & 2473 & 6 & 6 & 6 & 3 & 2 & 2 \\
\hline CDR. Siemianowice Śląskie & 2474 & 2 & 2 & 3 & 1 & 2 & 2 \\
\hline CDR. Sosnowiec & 2475 & 8 & 9 & 11 & 4 & 7 & 7 \\
\hline CDR. Świętochłowice & 2476 & 3 & 3 & 2 & 1 & 1 & - \\
\hline CDR. Tychy & 2477 & 6 & 6 & 7 & 2 & 2 & 3 \\
\hline CDR. Zabrze & 2478 & 4 & 4 & 4 & 1 & 2 & 4 \\
\hline CDR. Żory & 2479 & 2 & 1 & 1 & 1 & 1 & 1 \\
\hline & Total number & 227 & 262 & 233 & 66 & 145 & 99 \\
\hline
\end{tabular}

Table 8. Descriptive statistics of index of hazard sensitivity in years 2016-2018

\begin{tabular}{|c|c|c|c|c|c|c|c|c|}
\hline \multirow{2}{*}{ Year } & \multirow{2}{*}{$\begin{array}{c}\text { Number of } \\
\text { data }\end{array}$} & \multicolumn{9}{|c|}{ Index of hazard sensitivity IHS } \\
\cline { 3 - 9 } & & Mean & Minimum & Maximum & $\mathrm{Q}_{1}$ & $\mathrm{Me}$ & $\mathrm{Q}_{3}$ & Standard deviation \\
\hline 2016 & 66 & 0.48 & 0.015 & 3.0 & 0.14 & 0.33 & 0.66 & 0.55 \\
\hline 2017 & 145 & 0.68 & 0.014 & 4.0 & 0.14 & 0.33 & 0.7 & 0.91 \\
\hline 2018 & 99 & 0.56 & 0.028 & 4.0 & 0.12 & 0.33 & 0.8 & 0.62 \\
\hline
\end{tabular}


1 (insignificant contamination), for which the number of Legionella spp. did not exceed 100 CFU/100 mL. The probability of contamination category 1 for the S1 state varied from 0.39 to 0.68 . In the period of the conducted studies, the S1 state was found in $29 \%$ of the analysed swimming pool complexes in 2016, in 55\% in 2017 and in $42 \%$ in 2018 . The highest percentage share in contamination category $4(2.3 \%)$ was found in 2017. The conducted tests showed a systematic decrease in the number of events of microbiological contamination of water (the S1 state), generating the potential health risk for swimming pool users as a result of contamination of water with Legionella spp. (Table 9).

At the next step of analysis, for each of the 35 separated districts of the Silesian Voivodship, taken as the study areas for the conducted risk analyses, the index of area hazard sensitivity $I A H S_{k}$ was determined according to formula 3. This index, according to the research method, was determined for the districts where there is at least one swimming pool complex where the S1 water quality state occurred in the study period. The basic descriptive statistics were determined
(Table 10) for the obtained data set. The mean value of area hazard sensitivity in the study period was 2.07 (variability from 1.58 in 2016 to 2.35 in 2018). The minimum value of that index was determined in $2016\left(I A H S_{k}=0.04\right)$ for city with district rights Żory (CDR. Żory) and the maximum value $\left(I A H S_{k}=12\right)$ - in 2017 for the district of Racibórz (D. raciborski).

During the estimation of the health risk of swimming pool users in the $k^{\text {th }}$ study area in respect to the water contamination with $L e$ gionella spp., on the basis of the value of the load index of the swimming pool complex, weight $L I(S P C)_{k}$ was determined according to formula 7. For the set of random variables being the swimming pool complex load index, the basic descriptive statistics were determined in individual years of the study period (Table 11). In the analysed time horizon, the lowest load index of the swimming pool complex, amounting to 1.84 was determined for the district of Cieszyn (D. cieszyński) in 2017 (variability of 1.84-2.59). The lowest load index of the swimming pool complexes in that district is caused by the fact that - as a tourist region

Table 9. The probability of occurrence of water quality states in swimming pool complexes in the Silesian Voivodship in study period 2016-2018

\begin{tabular}{|c|c|c|c|c|c|}
\hline \multirow{4}{*}{ Year } & \multicolumn{5}{|c|}{ Water quality states } \\
\hline & \multirow{3}{*}{$\mathrm{S} 2$} & \multicolumn{4}{|c|}{$\mathrm{S1}$} \\
\hline & & \multicolumn{4}{|c|}{ Contamination category } \\
\hline & & 1 & 2 & 3 & 4 \\
\hline 2016 & 0.889 & 0.68 & 0.21 & 0.14 & 0.08 \\
\hline 2017 & 0.907 & 0.39 & 0.22 & 0.09 & 0.23 \\
\hline 2018 & 0.927 & 0.43 & 0.22 & 0.07 & 0.01 \\
\hline
\end{tabular}

Table 10. Descriptive statistics of index of area hazard sensitivity in years 2016-2018

\begin{tabular}{|c|c|c|c|c|c|c|c|c|}
\hline \multirow{2}{*}{ Year } & \multirow{2}{*}{$\begin{array}{c}\text { Number of } \\
\text { data }\end{array}$} & \multicolumn{7}{|c|}{ Index of hazard sensitivity IAHS } \\
\cline { 3 - 10 } & & Mean & Minimum & Maximum & Q1 & Me & Q3 & $\begin{array}{c}\text { Standard } \\
\text { deviation }\end{array}$ \\
\hline 2016 & 26 & 1.58 & 0.04 & 6.66 & 0.27 & 1.12 & 2.4 & 1.60 \\
\hline 2017 & 32 & 2.27 & 0.15 & 12.0 & 0.64 & 1.29 & 2.41 & 2.70 \\
\hline 2019 & 29 & 2.35 & 0.15 & 9.6 & 0.75 & 1.68 & 3.13 & 2.21 \\
\hline
\end{tabular}

Table 11. Descriptive statistics of load index of the swimming pool complex in years 2016-2018

\begin{tabular}{|c|c|c|c|c|c|c|c|c|}
\hline \multirow{2}{*}{ Year } & \multirow{2}{*}{$\begin{array}{c}\text { Number of } \\
\text { data }\end{array}$} & \multicolumn{7}{|c|}{ Load index of the swimming pool complex $L /(S P C)_{k}$} \\
\cline { 5 - 10 } & & Mean & Minimum & Maximum & Q1 & Me & Q3 & $\begin{array}{c}\text { Standard } \\
\text { deviation }\end{array}$ \\
\hline 2016 & 35 & 17.22 & 2.59 & 76.9 & 5.35 & 8.63 & 12.38 & 13.79 \\
\hline 2017 & 35 & 12.02 & 1.84 & 71.7 & 4.85 & 8.00 & 12.91 & 13.11 \\
\hline 2018 & 35 & 12.34 & 1.86 & 71.7 & 4.95 & 9.01 & 12.92 & 12.73 \\
\hline
\end{tabular}


a)

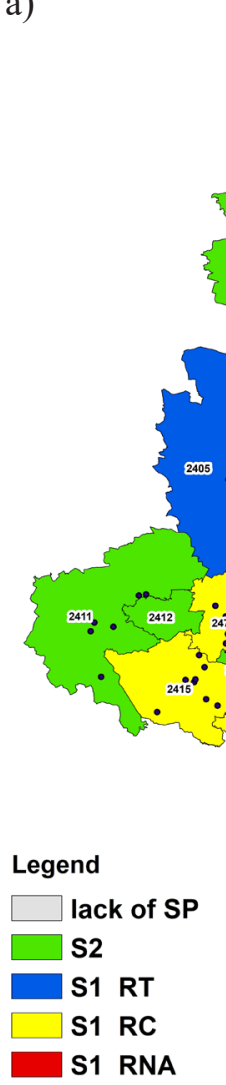

b)

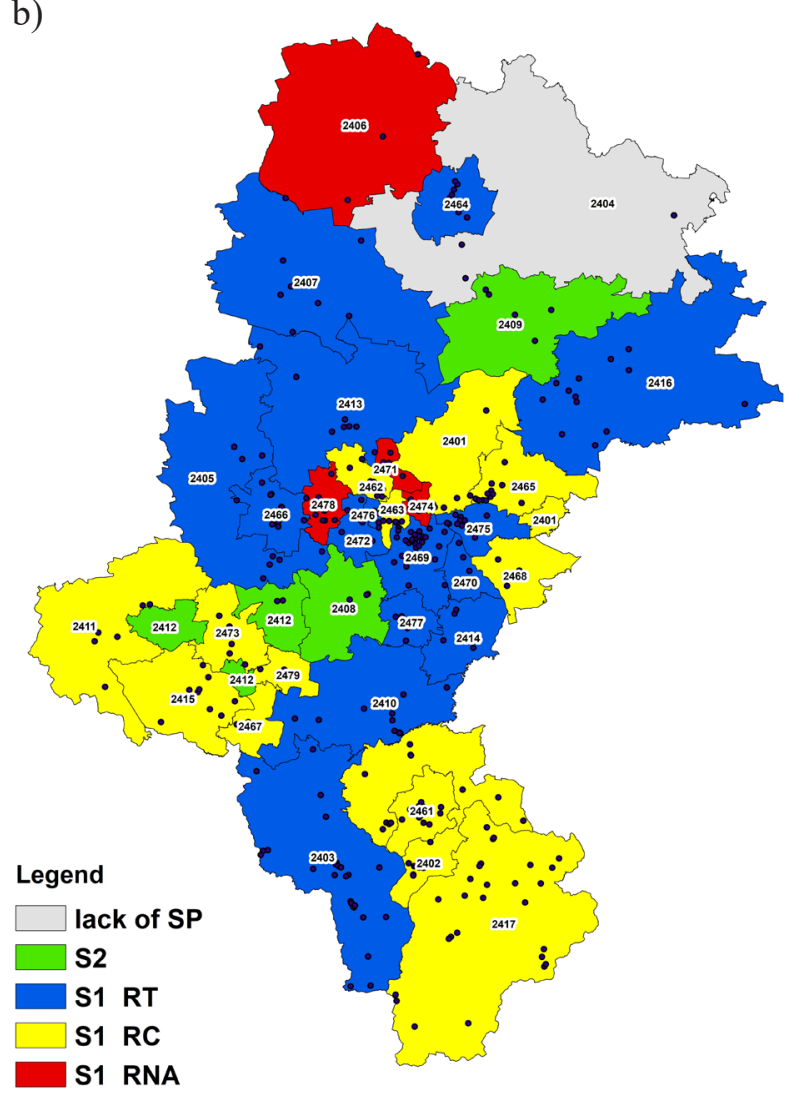

c)

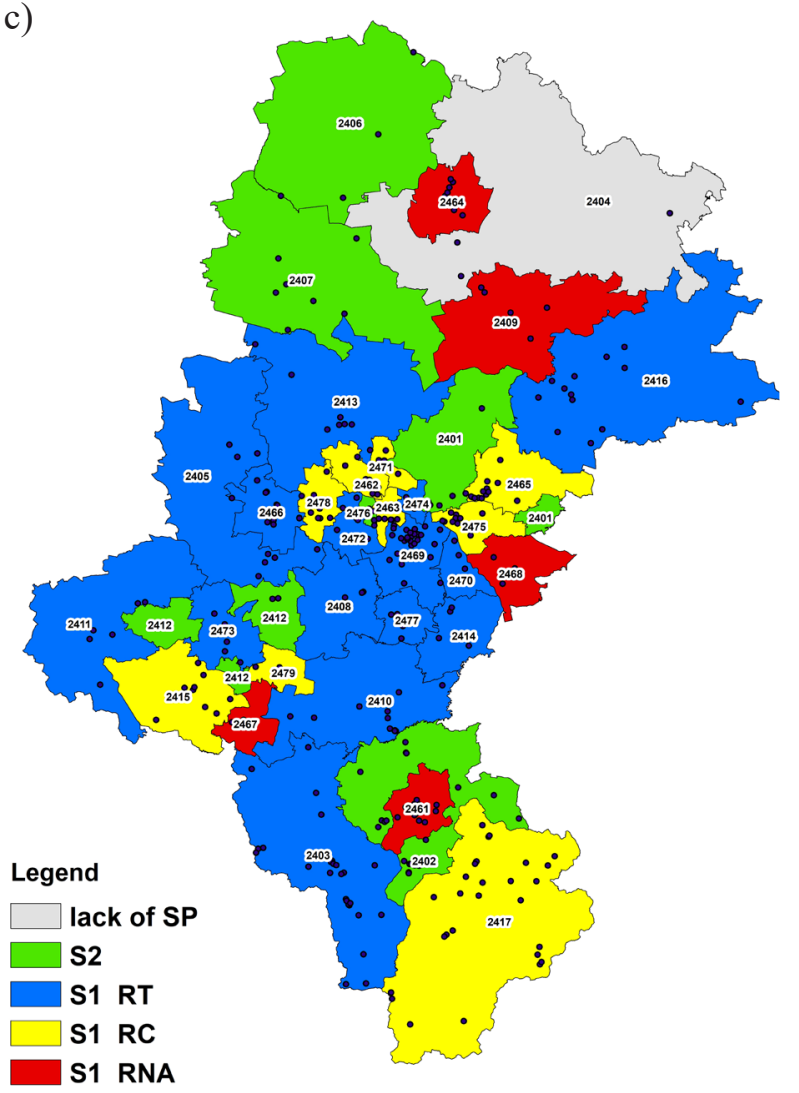

Fig. 1. Spatial interpretation of the health risk of swimming pool users in the Śląskie Voivodeship in the years: 1a) 2016 year; 1b) 2017 year; 1c) 2018 year: $\mathrm{SP}$ - swimming pool, S1 and S2 - water quality states, RT - Tolerated Risk, CR - Controlled Risk, UR - Unacceptable risk 
- it is characterised by a higher access to tourist attractions, which include swimming pool complexes. At the same time $40 \%$ of all aqua park complexes located in the Silesian Voivodship are located in that district. In 2018, there were 29 swimming pool complexes in the area of that district. The largest load index of the swimming pool complexes, being 76.9 was determined in 2016 for the district of Lubliniec (D. lubliniecki), where the variability of the index is at 10.3-76.9. Such a high amplitude of the index variability results from the launch of new facilities in years 2017-2018, compared to 2016.

On the basis of the conducted analysis of risk variables in the separated 35 research areas, proper weights were set out to index of area hazard sensitivity $I A H S_{k}$ and load index $L I(S P C)_{k}$. Subsequently, according to formula 7 , in the adopted study periods, the health risk for swimming pool users was determined in individual analysis areas as a result of contamination of the swimming pool water with Legionella spp. In the last step of research method, the determined risk values were categorised according to the assumed threshold values. Using GIS tools, the layer of spatial data of administrative borders was connected with the determined values of risk and a spatial variability of risk in individual study years was appointed (Fig. 1).

The conducted tests showed that in the swimming pools of the Silesian Voivodship, the $\mathrm{S} 2$ safety state throughout the time horizon occurred only in 3 districts (D. tarnogórski, D. bieruńsko-lędziński and the CDR. Gliwice). The randomness of occurrence pertaining to microbiological contaminations of water, and in turn the necessity of conducting a constant risk analysis for full safety of swimming pool users, are confirmed by the events occurring in the district of Kłobuck (D. kłobucki). In this district, a change from the S2 state in 2016 to the unacceptable risk in 2017 was found and then the S2 state was reinstated in 2018 as a result of the corrective actions and intense monitoring of the microbiological water quality. On average, in $42 \%$ of the study areas, there was the S1 state for tolerated risk. Unacceptable risk was identified:

- in 2016 year for 4 study areas: D. kłobucki, CDR Piekary Śląskie, CDR Siemianowice Śląskie, CDR Zabrze),
- in 2017 year for 5 study areas: D. myszkowski, CDR Bytom, CDR. Mysłowice, CDR. Piekary Śląskie CDR. Zabrze,

- in 2018 year for 5 study areas: D. myszkowski, CDR. Bielsko Biała, CDR. Częstochowa, CDR. Jastrzębie and CDR. Jaworzno.

\section{CONCLUSIONS}

The proposed research model allows for a quick assessment of the risk of exposure of the swimming pool complex users to waterborne diseases, including the Legionella spp.-induced diseases. The index of hazard sensitivity of microbiological water contamination be a part of opinion in procedures that support making administrative decisions containing an assessment of public health safety when using a given swimming pool complex.

The determination of health risk for the swimming pool complex users on the basis of index of area hazard sensitivity $I A H S_{k}$ and and load in$\operatorname{dex} \operatorname{LI}(S P C)_{k}$ allows obtaining quick information about the possibility of threat and the potential scale of dangerous events that may lead to a crisis. The information will allow proper services to prepare appropriate and effective means as well as corrective actions which are adequate to the scale of the risk. Moreover, spatial risk interpretations in the form of the proposed risk maps allow conscious decision making by users as regards use of swimming pool complexes in a given area.

The obtained analysis results for the swimming pool complexes in the Silesian Voivodship confirm the legitimacy of the obligation for a regular water testing for Legionella spp. According to the analysis, the authority for state swimming pool water control should strengthen the control activities in the areas of unacceptable risk in order to take effective corrective actions by the facility administrators, which will guarantee improved health safety for swimming pool complex users as a result of minimising the events generating the unacceptable risk.

\section{Acknowledgments}

This study was supported by the Ministry of Science and Higher Education of Poland within statutory funds - project no BK-259/RIE-4/2018. 


\section{REFERENCES}

1. Beauté J., Zucs P., de Jong B. 2013. On behalf of the European Legionnaires' Disease Surveillance Network. Legionnaires' disease in Europe, 2009-2010. Euro Surveillance, 2013, 18 (10), 6-12.

2. Beer D.K., Gargano J.W., Roberts V.A, Hill V.R., Garrison L.E., Kutty P.K, Hilborn E.D., Wade T.J., Fullerton K.E., Yoder J.S. 2015. Surveillance for Waterborne Disease Outbreaks Associated with Drinking Water — United States, 2011-2012, MMWR Mortal Weekly Report 64 (31), 842-848.

3. CDC. 2013. Surveillance for Waterborne Disease Outbreaks Associated with Drinking Water and Other Nonrecreational Water — United States, 20092010. Morbidity and Mortality Weekly Report, 62 (35), 714 - 724. Available from: https:/www.cdc. gov/mmwr/preview/mmwrhtml/mm6235a3.htm

4. Directive. 1998. Drinking Water Directive - Council Directive 98/83/EC of 3 November 1998 on the quality of water intended for human consumption. OJ L 330, 5.12.1998.

5. Directive. 2000. Water Framework Directive - Directive 2000/60/EC of the European Parliament and of the Council establishing a framework for the Community action in the field of water policy. OJ L327, 22.12.2000.

6. Directive. 2006. Bathing Water Directive - Directive 2006/7/EC of the European Parliament and of the Council of 15 February 2006 concerning the management of bathing water quality and repealing Directive 76/160/EEC. OJ L 64, 4.3.2006.

7. Goutziana G., Mouchtouri V.A., Karanika M., Kavagias A., Stathakis N.E., Gourgoulianis K., Kremastinou J, Hadjichristodoulou C. 2008. Legionella species colonization of water distribution systems, pools and air conditioning systems in cruise ships and ferries. BMC Public Health 8 (390), 1-13.

8. Lee Y. 2013. An Evaluation of Microbial and Chemical Contamination Sources Related to the Deterioration of Tap Water Quality in the Household Water Supply System. International Journal of Environmental Research 10 (9), 4143-4160.

9. Leoni E., Legnani P.P., Bucci Sabatini M.A., Righi
C. 2001. Prevalance of Legionella spp. in swimming pool environment. Water Research 35 (15), 3749-3753.

10. McCoy W.F., Downes E.L., Leonidas L.F., Cain M.F., Sherman D.L., Chen K., Devender S., Neville M.J. 2012. Inaccuracy in Legionella tests of building water systems due to sample holding time. Water Research 46 (11), 3497-3506.

11. Napoli, C., Fasano, F., Iatta, R., Barbuti G., Cuna T., Montagna M.T. 2010. Legionella spp. and legionellosis in southeastern Italy: disease epidemiology and environmental surveillance in community and health care facilities. BMC Public Health 10 (660), 1-17.

12. Polish Journal of Laws. 2015. Regulation of the Polish Minister of Health of 9 November 2015 on the requirements that should be met by swimming pool water. Polish J. Laws 2015. Item 2016 (in Polish). Available from:

13. http://prawo.sejm.gov.pl/isap.nsf/DocDetails. xsp?id=WDU20150002016

14. Polish Journal of Laws. 2017. Regulation of the Polish Minister of Health of 7 December 2017 amending the regulation on the quality of water intended for human consumption. Polish J. Laws 2017, Item 2294 (in Polish). Available from:

15. http://prawo.sejm.gov.pl/isap.nsf/DocDetails. xsp?id=WDU20170002294

16. Principe L., Tomao P., Visca P. 2017. Legionellosis in the occupational setting. Environmental Research 152, 485-495.

17. Roig J., Sabria M., Pedro-Botet M. 2003. Legionella spp.: community acquired and nosocomial infections. Current Opinion in Infectious Diseases 16 (2), 145-151.

18. SSI. 2019. State Sanitary Inspection - Data from Silesian State Voivodship Sanitary Inspector fram 2016-2018 years. Katowice (in Polish).

19. Statistics Poland. 2019. Materials of the Statistic Poland Office - number population in 2018 (in Polish). Available from: www.stat.gov.pl

20. Terranova W., Cohn M., Fraser D.W. 1978. 1974 Outbreak of Legionnaires' Disease Diagnosed in 1977: Clinical and Epidemiological Features. The Lancet 312 (8081), 122-124. 